\title{
PERSPECTIVES OF HYDROGEN PRODUCTION FROM CORN WASTES IN POLAND BY MEANS OF DARK FERMENTATION
}

\author{
PERSPEKTYWY PRODUKCJI WODORU W POLSCE OTRZYMANEGO \\ W WYNIKU CIEMNEJ FERMENTACJI ODPADÓW ZBOŻOWYCH
}

\begin{abstract}
A model for calculating the maximal theoretical production of hydrogen from corn wastes is proposed. The model has been used to estimate the potential for hydrogen production from cereals wastes such as wheat, barley, and corn which are cultivated in Poland. The potentials for Pomorze and other regions of Poland are compared. The hydrogen produced from cereal wastes in Poland could potentially meet $47 \%$ of national hydrogen demand.
\end{abstract}

Keywords: dark fermentation, theoretical hydrogen potential, Pomorze, wheat, barley, corn

\section{Introduction}

Dark fermentation is an anaerobic conversion of carbohydrates or glycerol into carbon dioxide, carboxylic acid and hydrogen. The process is a promising source of biohydrogen. Lignocellulose wastes can be considered as raw materials.

Urbaniec et al. [1, 2] and Grabarczyk et al. [1, 3, 4] analyzed sugar beet, wheat and potato as potential raw substrates for hydrogen production. Besides, paper-mill wastes [5] and sewage sludge [6] were analyzed. However, analysis gives results as a sum of photofermentation and fermentation of $1 \mathrm{~kg}$ of substrates used in Hyvolution programme $[5,7]$. Panagotiopulos et al. [8,9] works did not provide an exact explanation of the ratio for dark fermentation and dark fermentation in Hyvolution model. Hsu et al. [10] describe a technological pathway for hydrogen production from wastewater. Nasr et al. [11] models include hydrogen production profile over time using the Artificial Neuron Network (ANN) method. Sierra et al., Sangian et al., and Taufiq-Yap et al. [12-14] analyzed the energy potential of wood. The net energy generated by dark fermentation and microbial fuel cell is given by Perera et al. [15]. The dark fermentation process-parameters were analysed using CFD (computation fluid dynamics) codes in Trad et al. [16]. Singh et al. [17] analysed

\footnotetext{
${ }^{1}$ The Szewalski Institute of Fluid-Flow Machinery, Polish Academy of Sciences, ul. J. Fiszera 14, 80-231 Gdańsk, Poland, phone +48585225276

${ }^{2}$ Faculty of Mechanical Engineering, Gdansk University of Technology, ul. G. Narutowicza 11/12, 80-233 Gdańsk, Poland, phone +48 585225327

*Corresponding author: gsolowski@imp.gda.pl
} 
hydrogen production model based mainly on the empirical Gompertz Equation. There are also attempts related to kinetic modelling of process, similar to anaerobic digestion - see Chezeau et al. [18]. The dark fermentation experiments are based on corn, barley and wheat as the common substrates [19-23]. Li et al. [24] obtained empirically $9.4 \mathrm{~g}$ of hydrogen from $1 \mathrm{~kg}$ of corn straw. Nasirian et al. [25] found yield of $13.8 \mathrm{~g}$ of hydrogen from $1 \mathrm{~kg}$ of wheat waste, while $\mathrm{Wu}$ et al. [23] $8.3 \mathrm{~g}$ of hydrogen from $\mathrm{kg}$ of barley straw.

The aim of the investigation is to calculate the potential for production of hydrogen from cereal (wheat, barley and corn) wastes in all regions of Poland to determine availability of hydrogen substrates for dark fermentation. Therefore a model for estimation of hydrogen production from different lignocelluloses wastes has been proposed.

\section{Model description}

In the model, cellulose and hemicelluloses, the two biopolymers contained in lignocelluloses, are taken into account. The model presented allows for the calculation of potential hydrogen production from selected parts of plants.

The first assumption is that wastes coming from the same plants are in the same development stage and from the same cultivation area. Besides, a perfect hydrolysis of polysaccharides is assumed and that maximal hydrogen yield for hexoses is 0.33 and for pentoses is 0.32 - see Bartacek et al. [26] and Pradhan et al. [27]. The model includes such parameters as yield of reactions $Y_{t h}$ (for dark fermentation of hexoses) or $Y_{t p}$ (for dark fermentation of pentoses), mass of waste and fraction of biopolymers in the plant $\left(f_{c}\right.$ - for cellulose, $f_{h}$ - for hemicelluloses). The model was used to calculate the theoretical hydrogen production from selected lignocellulose wastes (wheat, barley, corn) based on the data for Pomorze and 15 other regions of Poland from the Agricultural Market Agency (ARR) [28]. The article uses a modified version of a model used by Solowski $[29,30]$.

It was assumed that wastes constitute $70 \%$ for wheat (63\% straw and $7 \%$ bran), $55 \%$ for barley and $48 \%$ for corn. The model assumes perfect hydrolysis of polysaccharides into simple carbohydrates (glucose, rhamnose, fructose, xylose, maltose and lactose) and acetic acid pathway of dark fermentation. The process of dark fermentation of simple carbohydrates can proceed according to two channels:

$$
\begin{gathered}
\mathrm{C}_{6} \mathrm{H}_{12} \mathrm{O}_{6}+4 \mathrm{H}_{2} \mathrm{O} \rightarrow 2 \mathrm{CH}_{3} \mathrm{COOH}+2 \mathrm{CO}_{2}+4 \mathrm{H}_{2} \\
\mathrm{C}_{5} \mathrm{H}_{10} \mathrm{O}_{5}+2.67 \mathrm{H}_{2} \mathrm{O} \rightarrow 1.67 \mathrm{CH}_{3} \mathrm{COOH}+1.67 \mathrm{CO}_{2}+3.33 \mathrm{H}_{2}
\end{gathered}
$$

with maximal theoretical yield of hydrogen $0.32-0.33[26,27]$.

The theoretical hydrogen production $M_{H i j}$ from the same waste part $j$ of plant $i$ :

$$
M_{H i j}=\left[f_{c j i} \frac{Y_{t h} M_{h e k H 2}}{M_{h e k}}+\left(\frac{Y_{t h} f_{h 6 j i} M_{h e k H 2}}{M_{h e k}}+\frac{Y_{t p} f_{h 5 j i M_{p e n H 2}}}{M_{p e n}}\right)\right] m_{j i}
$$

where the first term describes the hydrogen production from cellulose (biopolymer of glucose), the second and the third part describe the hydrogen production from hemicellulose (from hexoses and pentoses, respectively); $M_{H i j}$ - theoretical hydrogen production from waste part $j$ of plant $i ; m_{j i}$ - mass of waste part $j$ of plant $i ; f_{c j i}$ - fraction of cellulose in waste part $j$ of plant $i ; f_{h j i}$ - fraction of hemicellulose in waste part $j$ of plant $i$; $f_{h 6 j i}$ - fraction of hexoses in hemicellulose; $f_{h 5 j i}$ - fraction of pentoses in hemicellulose; $Y_{t h}$ - theoretical hydrogen yield from hexoses: (glucose, fructose, lactose) via reaction (1) 0.33 [26]; $Y_{t p}$ - theoretical hydrogen yield from pentoses: (xylose, rhamnose) via reaction 
(2) - 0.32 [27]; $M_{h e k H 2}$ - partial molar mass of hydrogen in hexose - $12 \mathrm{~g} \mathrm{~mol}^{-1} ; M_{\text {hek }}$ - molar mass of hexose - $180 \mathrm{~g} \mathrm{~mol}^{-1} ; M_{\text {penH2 }}$ - partial molar mass of hydrogen in pentose $10 \mathrm{~g} \mathrm{~mol}^{-1} ; M_{\text {pen }}$ - molar mass of pentose - $150 \mathrm{~g} \mathrm{~mol}^{-1}$.

The theoretical hydrogen production from plant $i$ can be obtained by summing over the waste parts $j$ of plant $i$ :

$$
M_{H i}=\sum_{j} M_{H i j}
$$

If plant $i$ belongs to spermatophytes, subset of the land plants, then $j$ can include: leaves, straw, seeds, flowers and roots (thus $j \in(1 ; 5)$ ). Here, for analysis only two $j$ parts (wheat straw and bran) were chosen. The assumed parameters for theoretical hydrogen production are given in Table 1. In this paper wheat straws, barley straws and corn straws were analyzed.

Table 1

Values of parameters for some of cereal wastes

\begin{tabular}{|c|c|c|c|c|c|}
\hline Material & $f_{c i i}$ & $f_{h i i}$ & $f_{h 5 j i}$ & $f_{h 6 j i}$ & Ref. \\
\hline Wheat straw & $40 \%$ & $26.6 \%$ & $0.23 f_{h j i}=6.1 \%$ & $0.76 f_{h i l}=20.5 \%$ & {$[20,31,32]$} \\
\hline Wheat bran & $42 \%$ & $21.2 \%$ & $0.29 f_{h j i}=6.1 \%$ & $0.71 f_{h j i}=15.1 \%$ & {$[33,34]$} \\
\hline Barley straw & $31 \%$ & $20.2 \%$ & $0.31 f_{h j i}=6.5 \%$ & $0.69 f_{h j i}=13.5 \%$ & {$[23,35]$} \\
\hline Corn straw & $38 \%$ & $26 \%$ & $0.3 f_{h i j}=7.8 \%$ & $0.7 f_{h j i}=18.2 \%$ & {$[36]$} \\
\hline
\end{tabular}

The theoretical hydrogen production from the wastes $M_{H}$ is calculated using the equation:

$$
M_{H}=\sum_{i} \sum_{j} M_{H i j}
$$

\section{Results and discussion}

\section{Results}

The model presented above was used for the estimation of potential hydrogen-production through the process of dark fermentation in Pomorze and other regions of Poland (Tables 2-6) using cereal waste estimated by ARR [28]. Finally, the region potentials are summarized to determine the potential for hydrogen production from cereal wastes across the whole of Poland (Table 6). Parameters $f_{c j i}$ and $f_{h j i}$ were assumed using data from literature [35-37].

The calculated potential hydrogen-production using dark fermentation from wastes of three basic cereals at Pomorze, Dolny Slask, Swietokrzyskie and Slask Voivodeships [28]

\begin{tabular}{|c|c|c|c|c|}
\hline Region & Material & $\begin{array}{c}\text { Annual mass of } \\
\text { wastes [Gg] }\end{array}$ & $\begin{array}{c}\text { Estimated mass } \\
\text { product [Gg] }\end{array}$ & $\begin{array}{c}\text { Estimated volume } \\
\text { product [Gm }\end{array}$ \\
\hline \multirow{4}{*}{ Pomorze } & Wheat straw & 400.4 & 5.8 & 651 \\
\cline { 2 - 5 } & Wheat bran & 45.7 & 0.6 & 71 \\
\cline { 2 - 5 } & Barley straw & 115.4 & 1.3 & 146 \\
\cline { 2 - 5 } & Corn straw & 7.9 & 0.1 & 12 \\
\cline { 2 - 5 } & Sum & 569.6 & 7.8 & 880 \\
\hline \multirow{4}{*}{ Dolny Slask } & Wheat straw & 764.4 & 10.4 & 1176 \\
\cline { 2 - 5 } & Wheat bran & 87.4 & 1.1 & 128 \\
\cline { 2 - 5 } & Barley straw & 233.7 & 1 & 210 \\
\cline { 2 - 5 } & Corn straw & 277.9 & 1.9 & \\
\hline
\end{tabular}




\begin{tabular}{|c|c|c|c|c|}
\hline \multirow{2}{*}{ Region } & Material & $\begin{array}{c}\text { Annual mass of } \\
\text { wastes [Gg] }\end{array}$ & $\begin{array}{c}\text { Estimated mass } \\
\text { product [Gg] }\end{array}$ & $\begin{array}{c}\text { Estimated volume } \\
\text { product [Gm }\end{array}$ \\
\hline \multirow{4}{*}{ Swietokrzyskie }
\end{tabular}

Table 3

The calculated potential hydrogen-production using dark fermentation from wastes of three basic cereals at Podlaskie, Lubelskie, Podkarpackie and Malopolska Voivodeship [28]

\begin{tabular}{|c|c|c|c|c|}
\hline Region & Material & $\begin{array}{c}\text { Annual mass of } \\
\text { wastes [Gg] }\end{array}$ & $\begin{array}{c}\text { Estimated mass } \\
\text { product }[\mathbf{G g}]\end{array}$ & $\begin{array}{c}\text { Estimated volume } \\
\text { product }\left[\mathrm{Gm}^{3}\right]\end{array}$ \\
\hline \multirow{5}{*}{ Podlaskie } & Wheat straw & 82.5 & 1.2 & 135 \\
\hline & Wheat bran & 9.4 & 0.1 & 15 \\
\hline & Barley straw & 39.0 & 0.4 & 50 \\
\hline & Corn straw & 10,5 & 0.1 & 17 \\
\hline & Sum & 153.1 & 1.9 & 216 \\
\hline \multirow{5}{*}{ Lubelskie } & Wheat straw & 662.4 & 9.9 & 1116 \\
\hline & Wheat bran & 75.7 & 1.1 & 118 \\
\hline & Barley straw & 225.7 & 2.5 & 286 \\
\hline & Corn straw & 45.5 & 0.6 & 72 \\
\hline & Sum & 1009.2 & 14.2 & 1592 \\
\hline \multirow{5}{*}{ Podkarpackie } & Wheat straw & 248.1 & 3.6 & 403 \\
\hline & Wheat bran & 28.4 & 0.4 & 44 \\
\hline & Barley straw & 54.2 & 0.6 & 68 \\
\hline & Corn straw & 45.4 & 0.6 & 70 \\
\hline & Sum & 376.1 & 5.3 & 584 \\
\hline \multirow{5}{*}{ Malopolska } & Wheat straw & 215.3 & 3.1 & 350 \\
\hline & Wheat bran & 24.6 & 0.3 & 38 \\
\hline & Barley straw & 94.1 & 1.1 & 117 \\
\hline & Corn straw & 36.1 & 0.5 & 56 \\
\hline & Sum & 276.1 & 5.0 & 561 \\
\hline
\end{tabular}

Table 4

The calculated potential hydrogen-production using dark fermentation from wastes of three basic cereals at Mazowieckie, Warmia-Mazury, Kujawy-Pomorze, Lodz Voivodeship [28]

\begin{tabular}{|c|c|c|c|c|}
\hline \multirow{2}{*}{ Region } & Material & $\begin{array}{c}\text { Annual mass of } \\
\text { wastes [Gg] }\end{array}$ & $\begin{array}{c}\text { Estimated mass } \\
\text { product [Gg] }\end{array}$ & $\begin{array}{c}\text { Estimated volume } \\
\text { product [Gm }\end{array}$ \\
\hline \multirow{4}{*}{ Mazowieckie } & Wheat straw & 284.0 & 4.1 & 461 \\
\cline { 2 - 5 } & Wheat bran & 32.5 & 0.5 & 50 \\
\cline { 2 - 5 } & Barley straw & 81.6 & 0.9 & 102 \\
\cline { 2 - 5 } & Corn straw & 41.5 & 0.6 & 65 \\
\cline { 2 - 5 } & Sum & 359.3 & 6.1 & 678 \\
\hline \multirow{3}{*}{$\begin{array}{c}\text { Warmia- } \\
\text { Mazury }\end{array}$} & Wheat straw & 405.5 & 5.9 & 72 \\
\cline { 2 - 5 } & Wheat bran & 46.4 & 0.6 & 235 \\
\cline { 2 - 5 } & Barley straw & 152.3 & 2.1 & 130 \\
\cline { 2 - 5 } & Corn straw & 83.0 & 1.2 & \\
\hline
\end{tabular}




\begin{tabular}{|c|c|c|c|c|}
\hline \multirow{2}{*}{ Region } & Material & $\begin{array}{c}\text { Annual mass of } \\
\text { wastes [Gg] }\end{array}$ & $\begin{array}{c}\text { Estimated mass } \\
\text { product [Gg] }\end{array}$ & $\begin{array}{c}\text { Estimated volume } \\
\text { product [Gm }\end{array}$ \\
\hline & Sum & 519.1 & 9.8 & 1094 \\
\hline \multirow{4}{*}{$\begin{array}{c}\text { Kujawy- } \\
\text { Pomorze }\end{array}$} & Wheat straw & 500.6 & 7.5 & 844 \\
\cline { 2 - 5 } & Wheat bran & 57.2 & 0.8 & 89 \\
\cline { 2 - 5 } & Barley straw & 275.5 & 3 & 331 \\
\cline { 2 - 5 } & Corn straw & 115.9 & 1.6 & 183 \\
\cline { 2 - 5 } & Sum & 936.0 & 12.9 & 361 \\
\hline \multirow{4}{*}{ Lodz } & Wheat straw & 222.3 & 3.2 & 40 \\
\cline { 2 - 5 } & Wheat bran & 25.4 & 0.4 & 108 \\
\cline { 2 - 5 } & Barley straw & 122.3 & 1 & 66 \\
\cline { 2 - 5 } & Corn straw & 42.3 & 0.6 & 569 \\
\cline { 2 - 5 } & Sum & 384.7 & 5.1 & \\
\hline
\end{tabular}

Table 5

The calculated potential hydrogen-production using dark fermentation from wastes of three basic cereals at Opole,

Wielkopolska, Lubusz and Pomorze Zachodnie Voivodeship according to ARR [28]

\begin{tabular}{|c|c|c|c|c|}
\hline Region & Material & $\begin{array}{c}\text { Annual mass of } \\
\text { wastes [Gg] }\end{array}$ & $\begin{array}{c}\text { Estimated mass } \\
\text { product }[\mathrm{Gg}]\end{array}$ & $\begin{array}{c}\text { Estimated volume } \\
\text { product }\left[\mathrm{Gm}^{3}\right]\end{array}$ \\
\hline \multirow{5}{*}{ Opole } & Wheat straw & 550.3 & 8 & 894 \\
\hline & Wheat bran & 62.9 & 0.8 & 97 \\
\hline & Barley straw & 192.3 & 2.2 & 240 \\
\hline & Corn straw & 205.6 & 2.9 & 321 \\
\hline & Sum & 1011.1 & 13.9 & 1552 \\
\hline \multirow{5}{*}{ Wielkopolska } & Wheat straw & 535.2 & 7.8 & 869 \\
\hline & Wheat bran & 61.2 & 0.8 & 94 \\
\hline & Barley straw & 374.0 & 4.2 & 467 \\
\hline & Corn straw & 277.4 & 2.8 & 312 \\
\hline & Sum & 1247.8 & 15.7 & 1742 \\
\hline \multirow{5}{*}{ Lubusz } & Wheat straw & 158.1 & 2.3 & 257 \\
\hline & Wheat bran & 18.1 & 0.3 & 28 \\
\hline & Barley straw & 48.3 & 0.5 & 60 \\
\hline & Corn straw & 24.1 & 0.3 & 38 \\
\hline & Sum & 248.5 & 3.4 & 382 \\
\hline \multirow{5}{*}{$\begin{array}{c}\text { Pomorze } \\
\text { Zachodnie }\end{array}$} & Wheat straw & 510.0 & 7.9 & 874 \\
\hline & Wheat bran & 58.3 & 0.8 & 90 \\
\hline & Barley straw & 156.0 & 5.6 & 622 \\
\hline & Corn straw & 19.4 & 0.3 & 30 \\
\hline & Sum & 743.7 & 14.5 & 1616 \\
\hline
\end{tabular}

Table 6

The potential total hydrogen production using dark fermentation from wastes of three basic cereals in Poland [28]

\begin{tabular}{|c|c|c|c|}
\hline Material & $\begin{array}{c}\text { Annual mass of wastes } \\
{[\mathbf{G g}]}\end{array}$ & $\begin{array}{c}\text { Estimated mass } \\
\text { product [Gg] }\end{array}$ & $\begin{array}{c}\text { Estimated volume } \\
\text { product [Gm }\end{array}$ \\
\hline Wheat straw & 5.8 & 90.6 & 10076 \\
\hline Wheat bran & 0.7 & 9.2 & 1022 \\
\hline Barley straw & 2.3 & 28.2 & 3142 \\
\hline Corn straw & 1.6 & 14.6 & 1623 \\
\hline Sum & 9 & 137.3 & 15272 \\
\hline
\end{tabular}

\section{Discussion}

The model presented in the paper enables the assessment of potential hydrogen production from cereal wastes by dark fermentation. It determines the upper limit of hydrogen production. The results present mass production (in $\mathrm{Gg}$ ) and volume production 
$\left(\right.$ in $\mathrm{Gm}^{3}$ ). The potential for hydrogen production in Poland is compared with recent data on world hydrogen demand [38]. The model uses parameters and data given in literature $[4,28]$.

The potential was obtained under assumption of perfect hydrolysis (all parts of biopolymers are converted into simple sugars) and so from $1 \mathrm{~kg}$ of selected crop wastes one obtains for:

- wheat straw - $14.6 \mathrm{~g}$ of hydrogen,

- wheat bran - $13.8 \mathrm{~g}$ of hydrogen,

- barley straw - $11 \mathrm{~g}$ of hydrogen,

- corn straw - up to $14 \mathrm{~g}$ of hydrogen.

This should be related to empirical results: $\mathrm{Li}$ et al. [24] obtained $9.4 \mathrm{~g}$ of hydrogen from $1 \mathrm{~kg}$ of corn straw; Nasirian et al. [25] $13.8 \mathrm{~g}$ of hydrogen from $1 \mathrm{~kg}$ of wheat waste, while Wu et al. [23] $8.3 \mathrm{~g}$ of hydrogen from $\mathrm{kg}$ of barley straw.

Due to high proportion of waste derived from corn and wheat, the highest production potential is in the Wielkopolska Region $1740 \mathrm{Gm}^{3}(15.7 \mathrm{Gg})$ followed by Dolny Slask Region $1629 \mathrm{Gm}^{3}$ (14.5 Gg), Pomorze Zachodnie Region $1616 \mathrm{Gm}^{3}$ (14.5 Gg), Lublin Region $1590 \mathrm{Gm}^{3}(14.2 \mathrm{Gg})$ and Opole Region $1552 \mathrm{Gm}^{3}(13.9 \mathrm{Gg})$. The potential hydrogen production using dark fermentation of cereal wastes in Pomorze Region is rather medium: $881 \mathrm{Gm}^{3}(7.8 \mathrm{Gg})$ of hydrogen (Table 2) half of the Wielkopolska Region $1740 \mathrm{Gm}^{3}(15.7 \mathrm{Gg})$, the region with the highest hydrogen potential (Table 5). The smallest hydrogen production potentials are in Podlaskie Region $216 \mathrm{Gm}^{3}(2 \mathrm{Gg})$, Lubusz Region $382 \mathrm{Gm}^{3}(3.4 \mathrm{Gg})$, Swietokrzyskie Region $400 \mathrm{Gm}^{3}(3.6 \mathrm{Gg})$ and Slask Region $414 \mathrm{Gm}^{3}$ (3.7 Gg).

The total Polish potential for hydrogen production from the crop waste adds up to $15272 \mathrm{Gm}^{3}(137.3 \mathrm{Gg})$ of hydrogen.

Polish potential of cereal wastes is equal $9 \mathrm{Pg}\left(\mathrm{P}=10^{15}\right.$ peta), which should be compared to $0.29 \mathrm{Gg}$ of textile wastes per year. The textile wastes are potentially more efficient in hydrogen production; from $1 \mathrm{~kg}$ of wastes one can potentially obtain:

- $21 \mathrm{~g}$ of hydrogen from cotton waste,

- $19 \mathrm{~g}$ of hydrogen from linen waste [29].

From textile wastes can be produced in Poland up to $6.6 \mathrm{Gm}^{3}(5.9 \mathrm{Gg})$ of hydrogen [29]. This can be compared with potential hydrogen production from wood wastes. From $1 \mathrm{~kg}$ of selected wood wastes can be potentially obtained using dark fermentation [30]:

- $16.9 \mathrm{~g}$ of hydrogen for pine wood 1-20 years old,

- $17.4 \mathrm{~g}$ of hydrogen for pine wood 21-40 years old,

- $15.9 \mathrm{~g}$ of hydrogen for pine wood 41-60 years old,

- $16.1 \mathrm{~g}$ of hydrogen for pine wood 61-80 years old,

- $\quad 13.2 \mathrm{~g}$ of hydrogen for pine wood 81-100 years old,

- $16.6 \mathrm{~g}$ of hydrogen for spruce wood 41-60 years old,

- $11.8 \mathrm{~g}$ of hydrogen for fir wood 1-20 years old,

- $11.9 \mathrm{~g}$ of hydrogen for fir wood 21-40 years old,

- $12 \mathrm{~g}$ of hydrogen for fir wood 41-60 years old,

- $\quad 12.1 \mathrm{~g}$ of hydrogen for fir wood 61-80 years old,

- $12.2 \mathrm{~g}$ of hydrogen for fir wood 81-100 years old,

- $17.5 \mathrm{~g}$ of hydrogen for beech wood 41-60 years old,

- $14.7 \mathrm{~g}$ of hydrogen for oak wood 1-20 years old, 
- $14.8 \mathrm{~g}$ of hydrogen for oak wood 21-40 years old,

- $15.6 \mathrm{~g}$ of hydrogen for oak wood 41-60 years old,

- $\quad 15.7 \mathrm{~g}$ of hydrogen for oak wood 61-80 years old,

- $16 \mathrm{~g}$ of hydrogen for oak wood 81-100 years old.

Lotos Group, the greatest consumer of hydrogen in Pomorze Region, used $45.9 \mathrm{Gg}$ of hydrogen in 2014. So, Polish potential of hydrogen production from cereal wastes $(137 \mathrm{Gg})$ exceeds the Lotos consumption almost 3 times. It constitutes also $47 \%$ of whole hydrogen consumption in Poland - $326517 \mathrm{Gm}^{3}(290.6 \mathrm{Gg})$ [29, 39].

Pomorze Region potential of hydrogen production from three cereals can substitute $2.7 \%$ of recent demand of hydrogen in Poland or $17 \%$ of Lotos demand. The Pomorze demand on hydrogen can be fulfilled by the combined hydrogen production from cereal wastes of several regions like Pomorze, Pomorze Zachodnie, and Warmia-Mazury (together $\left.5325 \mathrm{Gm}^{3}-47.9 \mathrm{Gg}\right)$.

The recent world hydrogen demand per year is $4 \mathrm{Pm}^{3}$; so, the Polish potential for hydrogen production from cereal wastes can fulfil only $0.3 \%$ of this demand [40, 41].

\section{Conclusions}

The availability of three cereals wastes as the source for hydrogen production by dark fermentation is discussed. The dark fermentation process is currently only a laboratory-scale process with no relevance for industry-scale demand. The perspectives given in this paper present upper limits of production of hydrogen by this method.

In Poland, the crop wastes of the three main cereals (wheat, corn and barley) can theoretically produce $137.3 \mathrm{Gg}$ of hydrogen, less than half of the country's recent demand for hydrogen and just $0.3 \%$ of the world demand. Pomorze can fulfill just $17 \%$ of its own regional demand for hydrogen derived from crop waste. The hydrogen production potential from cereal wastes is much higher than that from textile wastes due to the greater quantity of cereal wastes available $[26,29]$. Cereal wastes as a hydrogen source are comparable to wood waste but more easily achievable (less options and competition on the market) and more renewable (cereal grows faster than forest). Corn and wheat offer lower potential hydrogen yield per kg than pine, spruce, beech or oak wood but better than fir wood.

Wheat straw is the best hydrogen source from the three cereal wastes, slightly better than corn straw. The assessment of hydrogen production from different plant wastes is an important step in the efficient selection of substrates for hydrogen production. The data presented here can help in designing an industrial process for sustainable hydrogen production, which can contribute towards achieving a sustainable circular economy.

\section{Acknowledgements}

This research has been supported by the National Centre for Research and Development in Poland, under project no. BIOSTRATEG 3/344128/12/NCBR/2017 and grant of Institute of Fluid-Flow Machinery, Polish Academy of Science in Gdansk FBW-44 - G. Solowski.

\section{References}

[1] Urbaniec K, Grabarczyk R. Hydrogen production from sugar beet molasses - A techno-economic study. J Clean Prod. 2014;65:324-329. DOI: 10.1016/j.jclepro.2013.08.027. 
[2] Narasu ML, Urbaniec K. International conference on advances in biological hydrogen production and applications ICABHPA 2012. J Clean Prod. 2013;52:11-13. DOI: 10.1016/j.jclepro.2013.02.008.

[3] Urbaniec K, Grabarczyk R. Kierunki badań nad wykorzystaniem biomasy do otrzymywania wodoru. (Directions of studies on the use of biomass for production of hydrogen) Przem Chem. 2005;11:836-838. https://repo.pw.edu.pl/docstore/download/WUT356ca3b92b8e4e6e8c63fe93fa0d10fe/AzCz_2.pdf.

[4] Urbaniec K, Grabarczyk R. Raw materials for fermentative hydrogen production. J Clean Prod. 2009;17:959-962. DOI: 10.1016/j.jclepro.2009.02.008.

[5] Panagiotopoulos JA, Bakker RR, De Vrije T, Urbaniec K, Koukios EG, Claassen PAM. Prospects of utilization of sugar beet carbohydrates for biological hydrogen production in the EU. J Clean Prod. 2010;18:S9-S14. DOI: 10.1016/j.jclepro.2010.02.025.

[6] Kapdan IK, Kargi F. Bio-hydrogen production from waste materials. Enzyme Microb Technol. 2006;38:569-582. DOI: 10.1016/j.enzmictec.2005.09.015.

[7] Panagiotopoulos IA, Bakker RR, De Vrije T, Koukios EG, Claassen PAM. Pretreatment of sweet sorghum bagasse for hydrogen production by Caldicellulosiruptor saccharolyticus. Int J Hydrogen Energy. 2010;35:7738-7747. DOI: 10.1016/j.ijhydene.2010.05.075.

[8] Panagiotopoulos I, Dakker R, Vrije T, Niel E Van, Koukios E, et al. Exploring critical factors for fermentative hydrogen production from various types of lignocellulosic biomass. J Japan Inst Energy. 2011;90:363-368. DOI: 10.1046/j.1365-2559.2002.14891.x.

[9] Panagiotopoulos IA, Karaoglanoglou LS, Koullas DP, Bakker RR, Claassen PAM, Koukios EG. Technical suitability mapping of feedstocks for biological hydrogen production. J Clean Prod. 2014;102:521-528. DOI: 10.1016/j.jclepro.2015.04.055.

[10] Hsu CW, Lin CY. Commercialization model of hydrogen production technology in Taiwan: Dark fermentation technology applications. Int J Hydrogen Energy. 2016;41:4489-4497. DOI: 10.1016/j.ijhydene.2015.07.080.

[11] Nasr N, Hafez H, El Naggar MH, Nakhla G. Application of artificial neural networks for modeling of biohydrogen production. Int J Hydrogen Energy. 2013;38:3189-3195. DOI: 10.1016/j.ijhydene.2012.12.109.

[12] Sierra R, Garcia LA, Holtzapple MT. Selectivity and delignification kinetics for oxidative short-term lime pretreatment of poplar wood, part I: Constant-pressure. Biotechnol Prog. 2011;27:976-985. DOI: 10.1002/btpr.590.

[13] Sangian HF, Sehe MR, Tamuntuan G, Zulnazri Z. Utilization of saline solutions in the modification of lignocellulose utilization of saline solutions in the modification of lignocellulose from Champaca wood. J Korean Wood Sci Technol. 2018;46:368-379. DOI: 10.5658/WOOD.2018.46.4.368.

[14] Taufiq-Yap YH, Wong P, Marliza TS, Nurul Suziana NM, Tang LH, Sivasangar S. Hydrogen production from wood gasification promoted by waste eggshell catalyst. Int J Energy Res. 2013;37:1866-1871. DOI: 10.1002/er.3003

[15] Perera KRJ, Arudchelvam Y, Gadhamshetty V, Nirmalakhandan N. Modeling and simulation of net energy gain by dark fermentation. Int $J$ Hydrogen Energy. 2012;37:2267-2272. DOI: 10.1016/j.ijhydene.2011.10.059.

[16] Trad Z, Fontaine JP, Larroche C, Vial C. Multiscale mixing analysis and modeling of biohydrogen production by dark fermentation. Renew Energy. 2016;98:264-282. DOI: 10.1016/j.renene.2016.03.094.

[17] Singh V, Das D. Potential of Hydrogen-Production from Biomass. Science and Engineering of Hydrogen-Based Energy Technologies. Elsevier Inc.; 2018. DOI: 10.1016/b978-0-12-814251-6.00003-4.

[18] Chezeau B, Vial C. Modeling and Simulation of the Biohydrogen Production Processes. Elsevier B.V; 2019. DOI: $10.1016 / \mathrm{b} 978-0-444-64203-5.00019-8$.

[19] Ghimire A, Frunzo L, Pirozzi F, Trably E, Escudie R, Lens PNL, et al. A review on dark fermentative biohydrogen production from organic biomass: Process parameters and use of by-products. Appl Energy. 2015;144:73-95. DOI: 10.1016/j.apenergy.2015.01.045.

[20] Kaparaju P, Serrano M, Thomsen AB, Kongjan P, Angelidaki I. Bioethanol, biohydrogen and biogas production from wheat straw in a biorefinery concept. Bioresour Technol. 2009;100:2562-2568. DOI: 10.1016/j.biortech.2008.11.011.

[21] Panagiotopoulos IA, Bakker RR, Budde MAW, de Vrije T, Claassen PAM, Koukios EG. Fermentative hydrogen production from pretreated biomass: A comparative study. Bioresour Technol. 2009;100:6331-6338. DOI: 10.1016/j.biortech.2009.07.011.

[22] Tsapekos P, Kougias PG, Angelidaki I. Mechanical pretreatment for increased biogas production from lignocellulosic biomass; predicting the methane yield from structural plant components. Waste Manage. 2018;78:903-910. DOI: 10.1016/j.wasman.2018.07.017.

[23] Wu J, Ein-Mozaffari F, Upreti S. Effect of ozone pretreatment on hydrogen production from barley straw. Bioresour Technol. 2013;144:344-349. DOI: 10.1016/j.biortech.2013.07.001. 
[24] Li Q, Guo C, Liu CZ. Dynamic microwave-assisted alkali pretreatment of cornstalk to enhance hydrogen production via co-culture fermentation of Clostridium thermocellum and Clostridium thermosaccharolyticum. Biomass Bioenergy. 2014;64:220-229. DOI: 10.1016/j.biombioe.2014.03.053.

[25] Nasirian N, Almassi M. Optimization of biological hydrogen production process using stepwise regression method. Int J Biosci. 2014;6655:289-299. DOI: 10.12692/ijb/4.2.289-299.

[26] Bartacek J, Zabranska J, Lens PNL. Developments and constraints in fermentative hydrogen production. Biofuels, Bioprod Biorefining. 2007;1:201-214. DOI: 10.1002/bbb.17.

[27] Pradhan N, Dipasquale L, D'Ippolito G, Fontana A, Panico A, Lens PNL, et al. Kinetic modeling of fermentative hydrogen production by Thermotoga neapolitana. Int J Hydrogen Energy. 2016;41:4931-4940. DOI: 10.1016/j.ijhydene.2016.01.107.

[28] Agencja Rynku Rolnego. Rynek zbóż w Polsce (Corn Market in Poland). Warszawa: 2013. www.arr.gov.pl/data/00321/rynek_zboz_2013_pl.pdf.

[29] Sołowski G. Theoretical potential of hydrogen production from textiles wastes in Pomeranian region by means of dark fermentation. In: Noch T, Mikołajczewska W, Wesołowska A, editors. Globalizacja a regionalna ochrona środowiska, Gdańsk: Wydawnictwo Gdańskiej Szkoły Wyższej; 2016. 313-317. https://mostwiedzy.pl/pl/publication/theoretical-potential-of-hydrogen-production-from-textiles-wastes-inpomeranian-region-by-means-of-d,138189-1.

[30] Sołowski G. Hydrogen production from wood waste by mean of dark fermentation. In: Pikoń K, Czarnowska L, editors. Contemporary Problems of Power Engineering and Environmental Protection 2016. Gliwice: Published by Department of Technologies and Installations for Waste Management; 2016. 189-194. http://cleanalternative.eu/wp-content/uploads/2018/01/Merged_OSWE_book.pdf.

[31] Collins SR, Wellner N, Martinez Bordonado I, Harper AL, Miller CN, Bancroft I, et al. Variation in the chemical composition of wheat straw: the role of tissue ratio and composition. Biotechnol Biofuels. 2014;7:121. DOI: 10.1186/s13068-014-0121-y.

[32] Kongjan P, Angelidaki I. Extreme thermophilic biohydrogen production from wheat straw hydrolysate using mixed culture fermentation: Effect of reactor configuration. Bioresour Technol. 2010;101:7789-7796. DOI: doi.org/10.1016/j.biortech.2010.05.024.

[33] Cantero DA, Bermejo DM, Cocero JM. Reaction engineering for process intensification of supercritical water biomass refining. J Supercrit Fluids. 2015;96:21-35. DOI: 10.1016/j.supflu.2014.07.003.

[34] Pronyk C, Mazza G. Fractionation of triticale, wheat, barley, oats, canola, and mustard straws for the production of carbohydrates and lignins. Bioresour Technol. 2012;106:117-124. DOI: 10.1016/j.biortech.2011.11.071.

[35] Panagiotopoulos IA, Bakker RR, De Vrije T, Claassen PAM, Koukios EG. Dilute-acid pretreatment of barley straw for biological hydrogen production using Caldicellulosiruptor saccharolyticus. Int J Hydrogen Energy. 2012;37:11727-11734. DOI: 10.1016/j.ijhydene.2012.05.124.

[36] Karimi K, Taherzadeh MJ. A critical review on analysis in pretreatment of lignocelluloses: Degree of polymerization, adsorption/desorption, and accessibility. Bioresour Technol. 2016;203:348-356. DOI: 10.1016/j.biortech.2015.12.035.

[37] Merali Z, Ho JD, Collins SRA, Gall G Le, Elliston A, Käsper A, et al. Characterization of cell wall components of wheat straw following hydrothermal pretreatment and fractionation. Bioresour Technol. 2013;131:226-234. DOI: 10.1016/j.biortech.2012.12.023.

[38] Sołowski G, Shalaby MS, Abdallah H, Shaban AM, Cenian A. Production of hydrogen from biomass and its separation using membrane technology. Renew Sustain Energy Rev. 2017;82:3152-3167. DOI: 10.1016/j.rser.2017.10.027.

[39] Kozłowski K, Lewicki A, Malińska K, Wei Q. Current state, challenges and perspectives of biological production of hydrogen in dark fermentation process in Poland. J Ecol Eng. 2019;20:146-160. DOI: $10.12911 / 22998993 / 97270$.

[40] Nagasawa K, Davidson FT, Lloyd AC, Webber ME. Impacts of renewable hydrogen production from wind energy in electricity markets on potential hydrogen demand for light-duty vehicles. Appl Energy. 2019;235:1001-1016. DOI: 10.1016/j.apenergy.2018.10.067.

[41] Blanco H, Nijs W, Ruf J, Faaij A. Potential for hydrogen and power-to-liquid in a low-carbon EU energy system using cost optimization. Appl Energy. 2018;232:617-639. DOI: 10.1016/j.apenergy.2018.09.216. 